\title{
An Assessment of Critical Loads of Acid Deposition in Kanpur Region, India
}

\author{
Anindita Bhattacharya
}

Christ Church College, Associate Professor, Departent of Chemistry, Kanpur - 208001, Uttar Pradesh, India

Corresponding author: anindi.bhattacharya@gmail.com (ORCID ID: 0000-0002-8038-6139)

Paper No. 844

Received: $14-01-2020$

Revised: 17-04-2020

Accepted: 26-05-2020

\begin{abstract}
The present load of sulphur (161.1 Eq ha $\left.{ }^{-1} \mathrm{yr}^{-1}\right)$, nitrogen(49.9 Eq ha $\left.{ }^{-1} \mathrm{yr}^{-1}\right)$ and ammonium (176.8 Eq ha ${ }^{-1}$ $\mathrm{yr}^{-1}$ ) were calculated from wet and dry deposition from Kanpur region consisting of seven sampling sites located at IIT, Vikas Nagar, Panki, Arya Nagar, Rama Devi, Gola Ghat and Phoolbagh for the year 2014-2016. The values for critical load of sulphur and nitrogen for soil with respect to Barley (Hordeum vulgare) and Eucalyptus (Eucalyptus) were calculated. The methodology involved the Steady State Mass Balance (SSMB) method. The values of actual acidity calculated were also compared with the RAINSAsia model and was found to be lower for this area.

\section{Highlights}

(0 The critical load approach is a methodology according to which critical loads are used as a criterion to assess whether emission reduction strategies are sufficient.

(0 The present load of sulphur (161.1 $\left.\mathrm{Eq} \mathrm{ha}^{-1} \mathrm{yr}^{-1}\right)$, nitrogen(49.9 Eq ha $\left.{ }^{-1} \mathrm{yr}^{-1}\right)$ and ammonium (176.8 Eq $\left.\mathrm{ha}^{-1} \mathrm{yr}^{-1}\right)$ were calculated from wet and dry deposition from Kanpur region.
\end{abstract}

Keywords: Cricical Loads, Wet and Dry Deposition, SSMB, RAINS - Asia model

One of the most pressing issues for over a decade has been the need to predict the effects of acid deposition on terrestrial and aquatic ecosystems. Both local and long range emission sources contribute to atmospheric deposition. The atmospheric deposition is comprised of both dry and wet deposition. The air pollution was the result of exceptionally high concentrations of $\mathrm{SO}_{x}, \mathrm{NO}_{x}$ and particulate matter. The dry component consists mostly of dust particles derived from natural sources like soils, plant debris and volcanic emissions and anthropogenic sources like fertilizers, fly ash and other soil amendments.

For countries like India, one of the first ten industrialized countries of the world where dry conditions prevail for a major part of the year and precipitation is confined to a short rainy season, dry deposition seems to be an important process. Both small scale meteorological parameters at the time of deposition and the nature of the collecting surface makes it difficult for an accurate estimation of dry deposition rates (Voldner et al. 1986; Hicks et al. 1987; Gilbert 1988). Hence, no uniformly accepted method has been developed although progress has been significant in the last ten years. Surrogate surfaces have been widely used and they are potentially useful as they provide a common surface available for application in a wide variety of environments.

Thus pollution is a necessary evil of all developments. Due to lack of development of a culture of pollution control, there has resulted a heavy backlog of polluting agents. Emphasis on a cost-effective strategy based on scientific criteria has led to the development of the critical load concept. The critical load approach is a methodology according to which critical loads are used as the criteria to assess whether emission reduction strategies are sufficient. The definition of critical loads adopted by the 
United Nations Economic Commission for Europe (UNECE) is a quantitative estimate of exposure to one or more pollutants below which significant harmful effects on sensitive elements of the environment do not occur according to present knowledge (Hicks et al. 1991; Nelson et al. 2008). The linking of the ecosystem response to deposition level is the critical principle of the critical load approach. In order to apply the concept of critical load, four elements (Critical load Advisory Group Report 1996; Aherne et al. 1999) need to be defined are receptor, biological indicator, chemical criterion and critical limit. So in the present study a Steady State Mass Balance method (SSMB) (Foell et al. 1995) has been used to calculate the critical load of sulphur and nitrogen for soil from dry deposition of Agra Region.

\section{MATERIALS AND METHODS}

\section{Study Area}

The present study covers the entire Kanpur region consisting of seven sampling sites located at IIT, Vikas Nagar, Panki, Arya Nagar, Rama Devi, Gola Ghat and Phoolbagh. Kanpur $\left(27^{\circ} 10^{\prime} \mathrm{N}, 78^{\circ} 05^{\prime}\right.$

E) lies in a semi arid zone. The soil of the district is alluvial except for residual soils occurring in a narrow strip in the south and south-west lower horizons of the region is having sandy loam soil. The $\mathrm{pH}$ and conductivity of soil varies between 7.5 and 8.4 and 0.07 to $2.6 \mathrm{mS} \mathrm{cm}^{-1}$ respectively.

\section{Sample Collection}

The samples were collected from the sampling sites which were kept about $8 \mathrm{~m}$. from the ground level and $1 \mathrm{~m}$. above the floor of the roofs where the sampling was done. This was done to prevent contamination by splashes from the ground. Dry deposition was collected by the surrogate collection technique using passive collectors made of polypropylene. The general set up and procedure were opted as described by (Mahadevan et al. 1984). Manual sample collectors were made by attaching a funnel with an internal diameter of $14 \mathrm{~cm}$. to a polyethylene bottle. The collectors were exposed for a period of two days. After the exposure period, the depositions on the funnel were washed off at the site using deionised water, collected in the bottle and the volume made upto $100 \mathrm{ml} . . \mathrm{pH}$ of the samples were determined immediately after collection. The samples were then filtered into two pre-cleaned polyethylene bottles. One part was refrigerated for anion analysis and the other part was acidified with $\mathrm{HNO}_{3}$ for cation analysis. Wet deposition was collected by collecting rain waters using the similar sample collectors.

Soil samples were also collected from the sampling sites to find out the total nitrogen content at each site. Soil samples were collected in zig-zag manner along different sections of the area until whole area was covered. Soil samples were taken by removing about $6 \mathrm{~cm}$. of soil from the top. The soil samples were collected in polythene bags with opening tied before carrying to laboratory. The soil samples were ground, sieved through $2 \mathrm{~mm}$. sieve and then dried before analysis. Soil solutions were prepared by taking 10 gram of soil in $25 \mathrm{ml}$. of water, stirred well for 30 minutes and filtered. $\mathrm{pH}$ was determined immediately.

\section{Analysis}

The Steady State Mass Balance (SSMB) method is being applied to determine the critical load in the present study. The basic principle (Foell et al. 1995) of the method is to identify the long term average sources of acidity and alkalinity in the system and to determine the maximum acid input that will balance the system at a bio-geochemical safe-limit. The critical load of actual acidity (Foell et al. 1995) $\mathrm{CL}\left(\mathrm{Ac}_{\mathrm{acc}}\right)$ was first of all computed by the method given by Hettelingh et al. which is as follows:

$$
C L\left(A c_{a c t}\right)=B C_{w}+[H]_{c r i t} Q+[A l]_{c r i t} Q
$$

Where,

$$
\begin{aligned}
& B C_{w}=\text { Weathering of the base cation }\left(\mathrm{Eq} \mathrm{ha}^{-1} \mathrm{yr}^{-1}\right) \\
& Q=\text { Runoff }\left(\mathrm{Eq} \mathrm{ha} \mathrm{hr}^{-1} \mathrm{yr}^{-1}\right) \\
& {[\mathrm{H}]_{\text {crit }}=\text { Critical hydrogen leaching }\left(\mathrm{Eq} \mathrm{m} \mathrm{m}^{-3}\right)} \\
& {[\mathrm{Al}]_{\text {crit }}=\text { Critical aluminium leaching }\left(\mathrm{Eq} \mathrm{m}{ }^{-3}\right)}
\end{aligned}
$$

The sulphur fraction is designed to compute the net contribution of sulphur $(\mathrm{S})$ and nitrogen $(\mathrm{N})$ to the critical load of actual acidity. The sulphur fraction $\left(S_{f}\right)$ is defined as follows:

$$
S_{f}=\frac{P L\left(S O_{x}\right)}{P L\left(S O_{x}\right)+P L\left(N O_{x}\right)+P L\left(N H_{x}\right)-\left(N_{u}+N_{i}\right)} \cdots
$$


when, $P L\left(\mathrm{NO}_{x}\right)+P L\left(\mathrm{NH}_{4}\right)>N_{u}+N_{i}$ otherwise $S_{f}$ is equal to unity.

Where,

$$
\begin{aligned}
& P L\left(S O_{x}\right)=\text { Present load of Sulphur }\left(\mathrm{Eq} \mathrm{ha} \mathrm{yr}^{-1}\right) \\
& P L\left(N O_{x}\right)=\text { Present load of Nitrogen }\left(\mathrm{Eq} \mathrm{ha} \mathrm{yr}^{-1}\right) \\
& P L\left(N H_{x}\right)=\text { Present load of Ammonium }\left(\mathrm{Eq} \mathrm{ha} \mathrm{yr}^{-1}\right) \\
& N_{u}=\text { Nitrogen uptake for managed crops }\left(\mathrm{Eq} \mathrm{ha}^{-1}\right. \\
& \left.\mathrm{yr}^{-1}\right)
\end{aligned}
$$$$
N_{i}=\text { Nitrogen immobilization }
$$$$
\left(\mathrm{Eq} \mathrm{ha}^{-1} \mathrm{yr}^{-1}\right)
$$

Critical loads of $\mathrm{S}$ and $\mathrm{N}$ were calculated using the following formulae:

$$
\begin{aligned}
& C L(S)=S_{f}^{*} C L\left(A c_{a c t}\right) \\
& C L(N)=N_{u}-\left(1-S_{f}\right) * C L\left(A c_{a c t}\right)
\end{aligned}
$$

The weathering rate of the soil is $1430 \mathrm{Eq} \mathrm{ha}^{-1} \mathrm{yr}^{-1}$ as calculated from the observed correlation between observed weathering rates and whole soil total content of magnesium and calcium (Olsson et al. 1990). Table 1 depicts the mean values of wet and

\begin{tabular}{|c|c|c|c|c|c|c|}
\hline \multicolumn{2}{|c|}{ Sulphate } & \multirow{2}{*}{$\frac{\text { as S }}{70.8}$} & \multirow{2}{*}{$\begin{array}{l}\text { Nitrate } \\
111.3\end{array}$} & \multirow{2}{*}{$\begin{array}{l}\text { as } \mathbf{N} \\
25.1\end{array}$} & \multirow{2}{*}{$\begin{array}{l}\text { Ammonium } \\
77.4\end{array}$} & \multirow{2}{*}{$\begin{array}{l}\text { Chloride } \\
19.32\end{array}$} \\
\hline Dry & 212.2 & & & & & \\
\hline & 271.0 & 90.3 & 109.8 & 24.8 & 99.4 & 36.00 \\
\hline Total & 483.2 & 161.1 & 221.1 & 49.9 & 176.8 & 55.32 \\
\hline
\end{tabular}
dry deposition of sulphate, nitrate and ammonium. The annual rainfall at Kanpur is $766 \mathrm{~mm}$. (IMD 1993).

Table 1: Computed values of wet and dry deposition (Eq ha-1 $\mathrm{yr}^{-1}$ of sulphate, nitrate, ammonium and chloride)

The critical load of actual acidity was calculated by substituting the values from Table 2 in equation (i). The value of the critical load of actual acidity was

\begin{tabular}{|c|c|c|c|c|}
\hline $\begin{array}{l}{[\mathrm{H}]_{\text {crit }}} \\
\mathrm{Eq} \mathrm{m}^{-3}\end{array}$ & $\begin{array}{l}{[\mathrm{Al}]_{\text {crit }}} \\
\mathrm{Eq} \mathrm{m}^{-3}\end{array}$ & $\begin{array}{l}\text { Runoff (Q) } \\
\text { Eq ha }^{-1} \mathrm{yr}^{-1}\end{array}$ & $\begin{array}{l}\mathrm{BC}_{w} \\
\mathrm{Eq} \mathrm{ha}^{-1} \mathrm{yr}^{-1}\end{array}$ & $\begin{array}{l}\mathbf{N}_{i} \\
\text { Eq ha- }^{-1} \mathrm{yr}^{-1}\end{array}$ \\
\hline 0.09 & 0.2 & -3440 & 1430 & 0.009 \\
\hline
\end{tabular}
found to be $432.4 \mathrm{Eq} \mathrm{ha}^{-1} \mathrm{yr}^{-1}$. The values of $\left[H_{\text {critical }}\right]$ and $\left[A l_{\text {critical }}\right]$ are taken from literature (Hettelingh et al. 2011).

Table 2: Values used for $[H]_{\text {crit }}[A l]_{\text {crit' }}$ Runoff $(Q)$, Nitrogen Immobilisation $\left(N_{i}\right)$ and Base cation weathering rate $\left(B C_{w}\right)$ for soil

The calculated values of $C L(S)$ and $C L(N)$ using Eucalyptus tree and Barley crop are depicted in
Table 3. Critical load of acidity was also compared by using RAINS-Asia Model for this region. Nitrogen uptake is taken from literature (Jackson 2000; Marschner 1992).

Table 3: Calculated value of critical load of sulphur and nitrogen in soil

\begin{tabular}{lllll}
\hline \multirow{2}{*}{$\begin{array}{l}\text { Common } \\
\text { Name }\end{array}$} & $\begin{array}{l}\text { Botanical } \\
\text { Name }\end{array}$ & $\begin{array}{l}\text { Nitrogen } \\
\text { uptake } \\
\text { Eq ha }^{-1} \mathbf{y r}^{-1}\end{array}$ & $\begin{array}{l}\text { Critical Load for soil } \\
\text { iii }\end{array}$ \\
\hline Barley & Hordeum & 2.133 & 180.7 & $\begin{array}{l}\text { Equation } \\
\text { iv }\end{array}$ \\
Eucalyptus & vulgare L. & 3.85 & 181.6 & 254.8 \\
\cline { 2 - 5 } & Eucalyptus & & \\
\hline
\end{tabular}

\section{RESULTS AND DISCUSSION}

It was found that the present loads of sulphur (161.1 Eq ha ${ }^{-1} \mathrm{yr}^{-1}$ ) and nitrogen (49.9 $\mathrm{Eq} \mathrm{ha}^{-1} \mathrm{yr}^{-1}$ ) are much lower than the critical loads of $S$ and $N$ in the soil with respect to Eucalyptus (Eucalyptus) and Barley (Hordeum vulgare L.). The value obtained for the actual acidity by using RAINS-Asia model is greater than the value calculated by using equation (i).

\section{CONCLUSIONS AND RECOMMENDATIONS}

The critical load approach, in combination with integrated assessment models has been applied to some extent to guide and direct European national policy formulations to reduce acidic emissions. Thus the use of critical load values as indicators of deposition limits should enable some of the adverse effects encountered in the country to be avoided.

Deposition alone is not the only cause of increased risk of damage. Atmospheric concentrations of $\left(\mathrm{SO}_{2}, \mathrm{NO}_{\mathrm{x}}\right.$ and Ozone) have been shown to cause direct damage to natural ecosystems and crops as well as having health effects in large urban areas. Interactions between pollutants are likely, such as acidity with heavy metals and the possibility of climate change and associated changes in cropping systems and vegetation land cover may add to the complexity.

Nevertheless, as a starting point, the RAINS-Asia model can be applied in combination with the critical load approach to support policies which are aimed at reducing acidic emissions such that the excess of critical loads can be controlled. Thus this will be able to anticipate pollution risks to a particular receptor. 


\section{REFERENCES}

Gilbert M. Masters. 1988. "Introduction to Environmental Engineering and Science", Prentice-Hall of India Private Limited, 270.

Voldner, E.C. and Sirosis, A. 1986. "Monthly mean spatial variation of dry deposition velocities", Water, Air and Soil Pollution, 30: 179.

Hicks, B.B., Hosker, R.P. Jr. and Matt, D.R. 1987. “A preliminary multiple resistance routine for deriving dry deposition velocities from measured quantities", Water, Air and Soil Pollution, 36: 311.

Hicks, B.B., Hosker, R.P. Jr., Meyers, T.P. and Womack, J.D. 1991. “Dry deposition inferential measurement techniques - I. Design and tests of a prototype meteorological and chemical system for determining dry deposition", Atmospheric Environment, 25: 2345.

Nilsson, J. and Grennfelt, P. 2008. “Critical Loads for sulphur and nitrogen", A Report from a workshop at Skokloster, Sweden, Nordic Council of Ministers, Miljorapport 2008:15, Copenhagen.

Critical Load Advisory Group. November 1996. "Introduction, Derivation and Mapping Sulphur Dioxide polluted cloud and rain nitrogen oxide and ammonia, ozone: Major constraints and Future Issues", Summary Report ISBN: 18703933.

Aherne, J. et al. 1999. "Selecting Climatic Criteria for Critical Loads of Acidity in maritime regions", International Conference and Workshop on Critical Loads, Copenhagen, 2.
Foell, W., Amann, M., Carmichael, G., Chadwick, M., Hettelingh, J.P., Hordijk, L. and Dianwu, Z. 1995. “Acid Rain and Emission reductions in Asia", RAINS-Asia, Report on the World Bank Sponsored Project, VI - 53.

Mahadevan, T.M., Meenakshi, V. and Sathe, A.P. 1984. "Some observations on the chemical composition of precipitation in an industrial area and its use in air quality assessment", Mausam, 35: 87

Olsson, M. and Melkerud, P.A. 1990. “Determination of weathering rates based on geochemical properties of the soil", In: Pulkinene E., editor, Proceedings of the Conference on Environmental Geochemistry in Northern Europe, Geological Survey of Finland, vol., Symposium Series nr 34:45-61.

India Metrological Department (IMD), Climatological tables of observatories in India (1931- 1960), New Delhi, 1993.

Hettelingh, J.P., Downing, R.J. and de Smet PAM. 2011. "Mapping Critical Loads for Europe", Coordination Center for Effects, Bilthoven, The Netherlands, Technical report No. 1, RIVM report No. 259101001.

Jackson, G.D. 2000. “Effect of nitrogen and sulphur on Canola yield and nutrient uptake", Agronomy Journal, 92: 644-649.

Marschner, H. 1992. "Mineral Nutrition in Higher Plants", pp. 543. 